\title{
Studies in the Diabetic Mutant Mouse: IV. DBM, A Modified Diabetic Mutant Produced by Outcrossing of the Original Strain*
}

\author{
W.L. ChICK**, and A.A. LTKE*** \\ Elliott P. Joslin Research Laboratory, Departments of Medicine and Pathology, Harvard Medical School, The Peter \\ Bent Brigham Hospital and the Diabetes Foundation, Inc., Boston, Massachusetts, USA
}

Summary. Body weight, blood glucose, serum insulin and islet morphology were studied in DBM mice, modified diabetic mutants produced by crossing mice from the original black diabetic strain $(\mathrm{C} 57 \mathrm{BL} / \mathrm{Ks}-d b)$ with normal misty colored mice (C57BL/6J-m). DBM mutants appeared to live longer than most mice from the original strain. Only 1 of 6 animals, 7 months of age or older, showed the fall in body weight observed in the majority of the original mutants during the terminal stage of the disease. Blood glucose levels in both types of mutants were similar, generally reaching levels of 400 to $500 \mathrm{mg}$ glucose/100 ml blood. The mean insulin level in older (18 weeks or greater) DBM mutants was significantly greater than in the original mutants. These differences could be explained by the failure of DBM mutants to develop the marked decrease in numbers of beta cells seen in older mutants from the original strain.

Etudes de la mutation dbdb chez la souris. IV. DBM, un mutant diabétique modifié par croisement de la souche originelle

Résumé. Le poids corporel, les taux de glucose sanguin et d'insuline sérique ainsi que la morphologie des îlots sont étudiées chez la souris DBM, mutant diabétique modifié provenant du croisement d'animaux diabétiques noirs originaux (C 57 BL/Ks- $d b$ ) avec des souris normales grisâtres (C 57BL/6J-m). La souris DBM semble avoir une plus longue vie que la plus grande partie des animaux de souche originelle. Chez un animal sur $6,-$ âgés de 7 mois ou plus - on observe la diminution du poids corporel qui a lieu chez la plupart des mutants originaux pendant la période terminale de l'affection. Les taux de glucose sanguin mesurés chez les deux souches de mutants sont semblables, oscillant généralement entre 400 et $500 \mathrm{mg}$ glucose \%. Les taux moyens d'insuline circulante des mutants DBM plus âgés (18 semaines ou plus) sont signi. ficativement plus élevées que chez le mutant original. Ces différences peuvent s'expliquer par l'incapacité des mutants DBM de développer une diminution marquée du nombre de cellules comme elle se produit chez les mutants plus âgés de la souche initiale.

Der Diabetes der abdb-Maus: IV. DBM, eine modifizierte durch Kreuzung erhaltene diabetische Mutante

Zusammenfassung. Die Kreuzung von Tieren des ursprïnglichen Diabetesstammes $(d b)$ mit normalen grauen Mäusen ergab die modifizierte Mutante DBM. DBM-Mäuse scheinen länger zu leben als die Großzahl der Tiere des ursprünglichen $d b$-Stammes. Die bei $d b / d b$-Mäusen vom 7. Lebensmonat an regelmäßig beobachtete Gewichtsabnahme trat nur bei einem von 6 DBM-Tieren auf. Die Blutzuckerkonzentrationen beider Mutanten waren vergleichbar und schwankten zwischen 400 und $500 \mathrm{mg} / 100$ ml. Bei älteren DBM-Mäusen (ïber 18 Wochen) waren deutlich höhere Insulinkonzentrationen festzustellen als bei $d b / d b$. Diese Unterschiede mögen mit der Tatsache zusammenhängen, daß die Zahl der B-Zellen des Pankreas bei älteren DBM-Tieren weniger stark absinkt als bei $d b / d b$-Mäusen.

Key-words: DBM mouse, diabetic mutant mouse: genotype $\mathrm{C} 57 \mathrm{BL} / \mathrm{Ks}-d b / d b$, inherited diabetes, pancreatic islets, islets of Langerhans, blood glucose, serum insulin.
Since the initial report in 1966 [8], a number of publications have appeared dealing with various facets of the diabetic syndrome in the mutant mouse, C 57 $\mathrm{BL} / \mathrm{Ks}-d b / d b[3,4]$. The gross characteristies of the syndrome include the early appearance of obesity and hyperinsulinemia ( 3 to 4 weeks of age) followed by progressive hyperglycemia. The late stages of the disease are generally accompanied by weight loss and low levels of circulating immunoreactive insulin (IRI).

The gene responsible for the syndrome has been characterized as a unit autosomal recessive with complete penetrance $[8,3,4]$. Since diabetics are infertile, they must be produced by matings of known heterozygotes. Both heterozygotes and normal littermates, however, are similar in appearance (lean, black coat), and therefore can be definitely distinguished only by

* Supported in part by U.S.P.H.S. Grants AM-12538, AM-09584, AM-05077, and the John A. Hartford Foundation, Inc., New York, N. Y.

** U.S.P.H.S. Special Postdoctoral Fellowship Awardee, Grant F3-AM-36335.

*** U.S.P.H.S. Research Career Development Awardee, Grant $1 \mathrm{~K} 4$-AM-7394. trial breeding. In order to permit differentiation on a simpler basis, that of coat color, advantage was taken of the fact the $d b$ locus is closely linked to the misty (m) coat color gene (Group VIII linkage) [5]; mice heterozygous for the diabetes allele $(d b)$ were crossed with mice homozygous for the misty $(m)$ coat color. Offspring heterozygous for both $d b$ and $m$ (lean, black coat) were selected as progenitors of a new, balanced stock of diabetics (obese, black coat), referred to as DBM.

The present report compares alterations in body weight, blood glucose, serum IRI and pancreatic islet morphology in DBM mice with these same parameters in the original $\mathrm{C} 57 \mathrm{BL} / \mathrm{Ks}-d b / d b$ mutant. Additional studies dealing with glucose tolerance in DBM mutants and heterozygotes are presented in an accompanying report in this volume [2].

\section{Materials and Methods}

$D B M$ mutants. DBM mutants were from a colony produced and maintained in our laboratory. The colony was initiated using 5 mating pairs of mice provided by 
Dr. Katherine Hummel at The Jackson Laboratory (Fig. 1). The ancestors of these mating pairs were derived from a cross between a mouse homozygous for the misty $(m)$ coat color (C $57 \mathrm{BL} / 6 \mathrm{~J}-\mathrm{m} / \mathrm{m}$ ) and a black mouse heterozygous for the diabetes allele $d b$ (C 57 $\mathrm{BL} / \mathrm{Ks}-d b /+)$. $\mathrm{F}_{1}$ offspring heterozygous for both $m$ and $d b$ were selected as progenitors of the DBM stock.

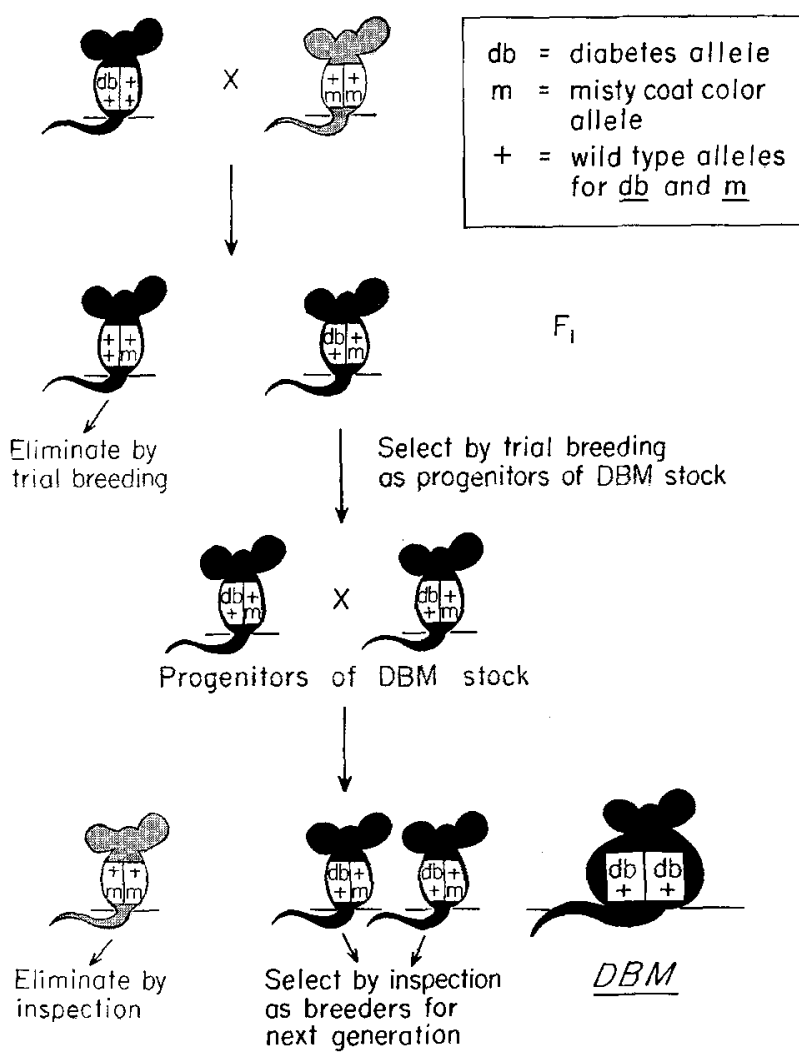

Fig. 1. Schematic representation of the matings used to produce DBM mutants and heterozygotes

Because of the close linkage between $m$ and $d b$, and the fact that the misty locus is in repulsion to the $d b$ allele (i.e., on the other chromosome) only 3 genotypes were produced by breeding these heterozygotes. These were obese black mice (DBM) homozygous for $d b(d b+1$ $a b+)$, lean black mice heterozygous for both $d b$ and $m$ $(+m / d b+)$ and misty mice homozygous for $m(+m)$ $+m)$. Thus mice heterozygous for $d b$ could be distinguished from both diabetics and normals and used as breeders of the next generation. These mice were brother-sister mated for 5 generations while at The Jackson Laboratory before the 5 mating pairs used to initiate our colony were selected.

Diet. All animals were fed ad lib with old Guilford mouse pellets ( $7.5 \%$ fat), and allowed free access to water.

Body weight, blood glucose and serum insulin determinations. Body weights were determined at weekly intervals. Blood glucose was measured at weekly or bimonthly intervals by the method of Hoffman [7], as modified for the Technicon Autoanalyzer, using $50 \mu \mathrm{l}$ samples of blood. IRI was measured in duplicate $50 \mu 1$ aliquots of serum by the double antibody method [11, 12], usually using samples obtained at the time of sacrifice by decapitation. IRI values, originally obtained. by assay against human insulin standards, were subsequently converted to mouse insulin units when purified mouse insulin standards became available late in the study $[9,10]$.

Pancreatic islet morphology. Representative DBM mutants of various ages were sacrificed and the pancreases fixed, embedded in paraffin and sectioned using conventional methods, as previously described [9].

Blood glucose, serum IRI and morphologic data for the original diabetic mutant (C $57 \mathrm{BL} / \mathrm{Ks}-d b / d b)$ and normal control (C $57 \mathrm{BL} / \mathrm{Ks}$ ) mice have already been presented in accompanying reports $[1,9,10]$ and specific findings are repeated here only for purposes of comparison with those in the DBM mutant.

Body weight. An early distinguishing abnormality in DBM mutants, similar to that in mutants from the original $d b$ strain, was the increased deposition of fat in the inguinal and axillary regions, evident as early as $\mathbf{3}$ to 4 weeks of age. Generally by 2 to 3 months of age both types of mutants weighed 50 to $60 \mathrm{~g}$, roughly twice that of normal adult mice. Beyond this period, however, significant differences became apparent between the two groups of mutants (Fig. 2). The majority

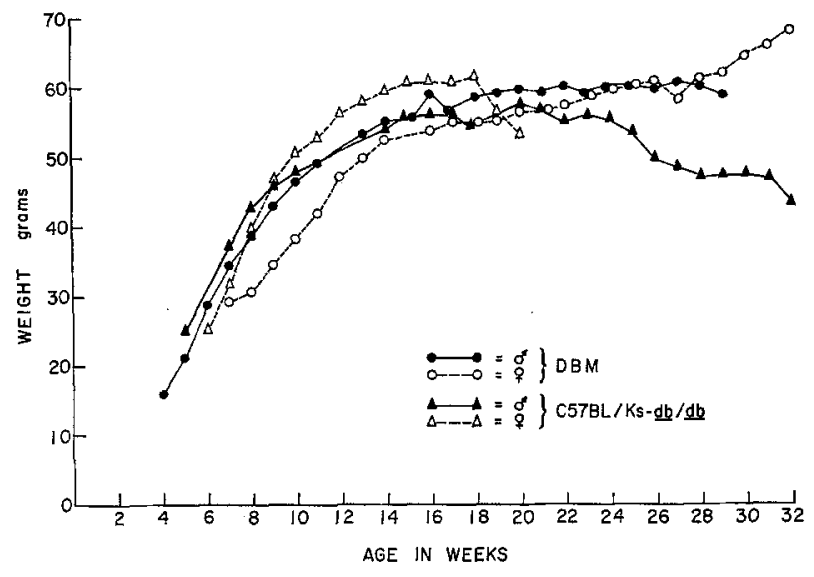

Fig. 2. Body weight vs. age in representative male and female DBM and $\mathrm{C} 57 \mathrm{BL} / \mathrm{Ks}-d b / d b$ diabetic mutant mice

of diabetics from the original strain developed gradual weight loss and usually succumbed by 5 to 7 months of age $[8,3,4,9]$. In contrast, among the colony of DBM mutants, which included 6 mice 7 months of age or older, only a single animal lost weight, and as yet no spontaneous deaths have occurred.

Blood glucose and serum insulin. The average blood glucose concentrations at various ages in both types of mutants is shown in Fig. 3. The pattern of development of hyperglycemia in both groups was similar. Although at 5 weeks of age the average blood glucose concentration was only slightly above normal, by the 
7 th week a more distinct elevation was apparent. There was a further increase in hyperglycemia until approximately 15 weeks of age, when values stabilized in the range of 400 to $500 \mathrm{mg}$ glucose $/ 100 \mathrm{ml}$ blood. Although 2 animals from the original strain manifested even more marked hyperglycemia, with levels of 636 and $828 \mathrm{mg}$ glucose $/ 100 \mathrm{ml}$ blood, the highest value observed in a DBM mutant was $572 \mathrm{mg}$ glucose $/ 100 \mathrm{ml}$ blood.



Fig. 3. Blood glucose vs. age in DBM and C 57 BL/Ks- $d b / d b$ diabetic mutant mice. Glucose concentrations are means \pm S.E.M. The small numerals indicate the number of animals for each point

Table. Comparison of serum IRI levels in DBM and $C 57 \mathrm{BL} / \mathrm{Ks}$-db/db diabetic mutant mice

\begin{tabular}{llll}
\hline Group & Number of mice & $\begin{array}{l}\text { Agea } \\
\text { (weeks) }\end{array}$ & $\begin{array}{l}\text { Serum } \\
\text { IRIb }^{\mathrm{b}} \\
(\mu \mathrm{U} / \mathrm{ml})\end{array}$ \\
\hline $\mathrm{C} 57 \mathrm{BL} / \mathrm{Ks}-d b / d b$ & 15 & $\begin{array}{l}18 \text { to } 36 \\
(23)\end{array}$ & $101 \pm 22$ \\
DBM & 7 & $\begin{array}{l}\mathbf{1 8} \text { to } 32 \\
(25)\end{array}$ & $\begin{array}{l}P<0.005 \\
\mathbf{3 3 7} \pm 97\end{array}$ \\
\hline
\end{tabular}

a Range of ages; mean age in parenthesis

b Mean \pm S.E.M.

$P$ is the probability computed from the Student $t$-test.

In contrast to blood glucose concentrations, a definite difference was apparent in serum IRI levels in the two groups. While the average serum IRI concentration in the original mutants was highest during the initial phases of the syndrome, it eventually returned to normal during the terminal stage of the disease $[9,10]$. Serum IRI levels in most old DBM mutants, however, remained considerably elevated above normal. Serum IRI levels in both groups of mutants, 18 weeks of age and older, are compared in the Table. It is apparent that older DBM mutants are capable of maintaining a significantly higher serum IRI level $(P<$ $0.005)$.
Pancreatic islet morphology. Although the appearance of the islets was similar in both groups of mutants during the early phases of the disease, striking differences became apparent with progressive ageing (Fig. 4). In mutants from the original strain the typically oval or circular islet, sharply delineated from the surrounding exocrine pancreas, was frequently replaced by islets having an irregular contour. Collections of acinar cells were often present within the islets. Numerous small and sometimes dilated ductal structures surrounded and often permeated the interior of the islet. In association with these intra-islet ductal structures, there was a clear-cut decrease in the number of beta cells [7]. In contrast, the large majority of islets of DBM mutants were well delineated from the surrounding exocrine tissue and failed to demonstrate this unique proliferation of ductal structures. To date, the islets of only one DBM mutant mouse have revealed significant evidence of ductal proliferation. This animal also had a low serum IRI.

\section{Discussion}

The present results illustrate a number of similarities and differences between DBM mutants and mutants from the original (C $57 \mathrm{BL} / \mathrm{K}_{\mathrm{s}-} d b$ ) strain of mice. The similarities include the early appearance ( 3 to 4 weeks of age) of hyperinsulinemia and obesity, followed by progressively severe hyperglycemia. The differences include the fact that DBM mutants appear to live longer, and rarely manifest the fall in body weight and low serum IRI levels observed during the terminal phase of the disease in mutants from the original strain.

These differences are in turn explained, at least in part, by the observation that DBM mutants do not develop the marked decrease in numbers of beta cells seen during the terminal phase of the syndrome in diabetics from the original strain [9]. This decrease in the size of the beta cell population might be expected to lead to low levels of serum IRI, and thus a decline in body weight. Furthermore, since overeating, obesity and hyperglycemia are present in both groups of mutants, they are insufficient causes to account fully for the structural alterations which occur in islets of mutants from the original strain.

It appears that crossing of the original mutant with $\mathrm{C} 57 \mathrm{BL} / 6 \mathrm{~J}-\mathrm{m}$ mice has resulted in a change in some of the genetic factors which determine the severity of the diabetic syndrome. Such experiments offer a potential means for more precise evaluation of the genetic mechanisms responsible for different facets of the disease.

Acknowledgement. The authors acknowledge the skillful technical assistance of Miss Judith Flewelling and Miss Pauline Gaudreau.

\section{References}

1. Chick, W.L., Like, A.A.: Studies in the diabetic mutant mouse: III. Physiological factors associated 
Fig. 4. Pancreatic islets of older diabetic mutants from both strains

a. $\mathrm{C} 57 \mathrm{BL} / \mathrm{Ks}-d b / d b$ mutant 6 months of age. ( $\mathrm{H}$ and $\mathrm{E}$ stain $256 \times)$

b. DBM mutant 8 months of $(\mathrm{H}$ and $\mathrm{E}$ stain $256 \times$ ).
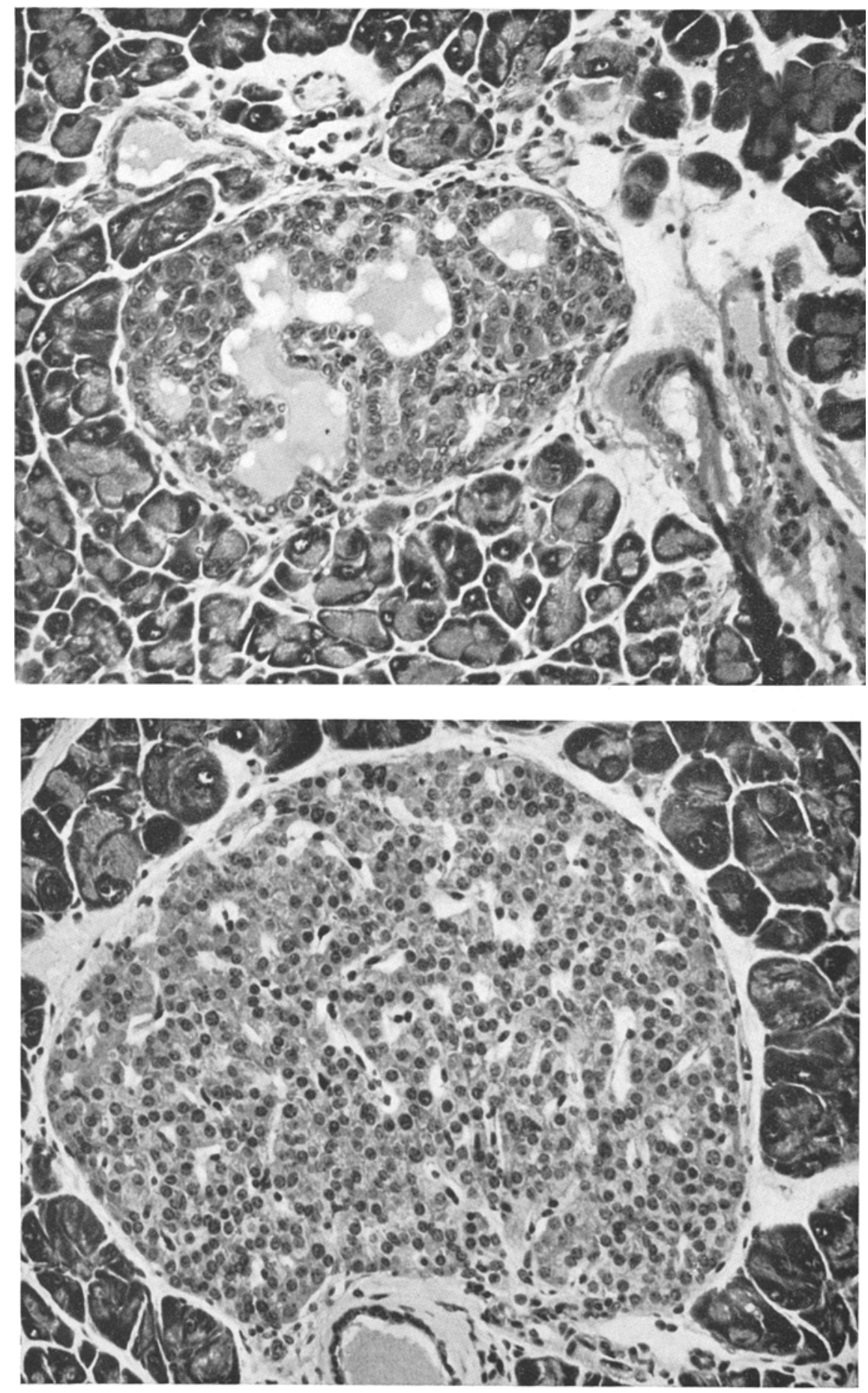

with alterations in beta cell proliferation. Diabetologia 6, 243-251 (1970).

2. - Lavine, R.L., Like, A.A.: Studies in the diabetic mutant mouse. V. Glucose tolerance in mice homozygous and heterozygous for the diabetes $(d b)$ gene. Diabetologia 6, 257-262 (1970).

3. Coleman, D.L., Hummel, K.P.: Studies with the mutation, diabetes, in the mouse. Diabetologia 3 , $238-248(1967)$
4. - - The mutation, diabetes, in the mouse. In: "Diabetes, Proceedings of the SixthlCongress of the International Diabetes Federation", Östman, J., Ed., Milner, R.D.G., Co-Ed., pp. 813-820. Amsterdam: Excerpta Medica Foundation 1969.

5. - - Quoted as personal communication from P. Lane.

6. Davoren, P.R.: The isolation of insulin from a single cat pancreas. Biochin. biophys. Acta 63, 150-153 (1962). 
7. Hoffman, W.S.: A rapid photoelectric method for determination of glucose in blood and urine. J. biol. Chem. 120, 51-55 (1937).

8. Hummel, K.P., Dickie, M.M., Coleman, D.L.: Diabetes, a new mutation in the mouse. Science 153, $1127-1128$ (1966).

9. Like, A.A., Chick, W.L.: Studies in the diabetic mutant mouse: I. Light microscopy and radioautography of pancreatic islets. Diabetologia 6, 207-215 (1970).

10. - - Studies in the diabetic mutant mouse: II. Electron microscopy of pancreatic islets. Diabetologia 6 , $216-242(1970)$.
11. Morgan, C.R., Lazarow, A.: Immunoassay of insulin: two antibody system. Diabetes 12, 115-126 (1963).

12. Soeldner, J.S., Slone, D.: Critical variables in the radioimmunoassay of serum insulin using the double antibody technique. Diabetes 14, $771-779$ (1965).

William L. Chick, M. D.

Elliott P. Joslin Research Laboratory 170 Pilgrim Road.

Boston, Massachusetts 02215, USA 